\title{
МОРФОЛОГІЧНІ ЗМІНИ У СКЕЛЕТНИХ М'ЯЗАХ ЗАДНІХ КІНЦІВОК ЩУРІВ ПРИ ГОСТРІЙ ІШЕМІЇ-РЕПЕРФУЗІЇ, СПРИЧИНЕНІЙ НАКЛАДАННЯМ АРТЕРІАЛЬНОГО ТУРНІКЕТА, ТА ІІЇ КОРЕКЦІЇ КАРБАЦЕТАМОМ
}

\begin{abstract}
Морфологічні зміни у скелетних м'язах задніх кінцівок щурів при гострій ішемії-реперфузії, спричиненій накладанням артеріального турнікета, та її корекції карбацетамом

Т. О. Вересюк, П. Р. Сельський, А. Т. Телев'як, Б. П. Сельський

Тернопільський національний медичний університет імені І. Я. Горбачевського МОЗ України
\end{abstract}

Резюме. Артеріальні турнікети широко застосовуються як у клінічній практиці (зокрема при ангіо- та артропластиках), так і у військовій медицині при пораненнях кінцівки. Після зняття турнікета і відновлення кровопостачання кінцівки виникає мультифракторне ішемічно-реперфузійне ураження як первинно ішемізованих, так і віддалених від місця ішемії тканин. Вивченню морфологічних порушень у м'язовій тканині при гострій ішемії-реперяруії у медичній літературі присвячено низку публікацій. Проте тривають пошуки ефрективних середників для медикаментозної корекції даних порушень.

Мета дослідження - провести порівняльний аналіз структурних змін у скелетних м'язах задніх кінцівок щурів при гострій ішемії-реперфузії, спричиненій накладанням артеріального джгута, при здійсненні корекції порушень карбацетамом.

Матеріали і методи. Проведено мікроскопічне дослідження гістологічних зрізів скелетних м'язів задніх кінцівок 60 щурів нижче ділянки накладання джгута за умов експериментальної гострої ішемії-реперфузії. Гостру ішемію усім тваринам викликали шляхом накладання гумових джгутів SWAT на задні кінцівки тварин шириною 5-6 мм, на рівні пахвинної складки протягом 2 год під тіопенталовим знеболюванням, а реперфузію моделювали шляхом зняття турнікета. Половині експериментальних тварин у реперфузійному періоді з метою корекції внутрішньочеревно вводили ноотропний препарат «Карбацетам» в дозі 5 мг на кілограм маси тіла один раз на добу протягом усього реперфузійного періоду. Зрізи скелетних м'язів забарвлювали гематоксиліном і еозином, за ван Гізон та азаном за методом Гейденгайна і вивчали за допомогою світлового мікроскопа.

Результати. Дослідження показали, що у ранньому реперфузійному періоді морфологічними критеріями ремоделювання скелетних м'язів були виражений набряк м'язових волокон та ендо- і перимізію, порушення у гемомікроциркуляторному руслі у вигляді стазу, гіперемії та
Morphological changes in skeletal muscles of the hind limbs of rats in acute ischemia-reperfusion caused by arterial tourniquet application, and its correction by carbacetam

T. O. Veresiuk, P. R. Selskyy, A. T. Televiak,

B. P. Selskyy

I. Horbachevsky Ternopil National Medical University

e-mail: totel@ukr.net

Summary. Arterial tourniquets are widely used both in clinical practice (for example for angio- and arthroplasty) and in military medicine by the injury of the limbs. After removing the tourniquet and blood supply restoration to the limb arises a multifactorial lesion of tissues both ischemic and distant from the site of ischemia. A number of publications have been devoted to the study of morphological disorders in muscle tissue in acute ischemia-reperfusion in the medical literature. However, the search for effective means for drug correction of these disorders still continues.

The aim of the study - to conduct a comparative analysis of structural changes in the skeletal muscles of the hind limbs of rats in acute ischemia-reperfusion caused by the application of an arterial tourniquet, using the correction of disorders with carbacetam.

Materials and Methods. Microscopic examination of histological sections of skeletal muscles of the hind limbs of 60 rats below the site of application of the tourniquet under conditions of experimental acute ischemia-reperfusion was performed. Acute ischemia for all animals was caused by application of SWAT rubber bands on the hind limbs of animals, 5-6 $\mathrm{mm}$ in width, at the inguinal fold level within 2 hours under thiopental anesthesia. A reperfusion was modeled by removing the tourniquet. Half of the experimental animals in the reperfusion period for the purpose of correction intraperitoneally was administered the nootropic drug 1-oxo-3,3,6-trimethyl1,2,3,4-tetrahydroindolo[2,3-c]quinoline (carbacetam) at a dose of $5 \mathrm{mg}$ per kilogram of body weight once a day during the entire reperfusion period. The histological examination was carried out according to standard methods. Sections of the arteries were stained with hematoxylin and eosin, with resorcinol-fuchsin according to Weigart, according to method of Van Gizon and with azan according to the method of Heidenhain, and were examined with a light microscope.

Results. Studies have shown that in the early reperfusion period morphological criteria for skeletal muscle remodeling expressed by swelling of muscle fibers and endo- and 
мікротромбозу, діапедезні крововиливи, виражена лейкоцитарна інфрільтрація, деформація м'язових волокон та втрата їх посмугованості, ушкодження сарколеми з виходом ядер у ендомізій, розволокнення міофібрил, розриви та оррагментація волокон, порушення лінійного розміщення ядер у них, поява ділянок міоцитолізу. За умови корекції реперфузійних порушень карбацетамом відбувається зменшення ступеня ураження та пришвидшення відновлення структури скелетних м'язів, яке найбільш яскраво виявлялося в групах тварин із термінами реперсрузії через 1 та 7 діб. Сукупність ознак свідчить про те, що на тканинному рівні при введенні карбацетаму не лише зменшується ішемічно-реперфузійне ураження міосимпласта, але також пришвидшуються механізми репаративного рабдоміогістогенезу.

Висновки. Структурні зміни у скелетних м'язах кінцівки при двогодинній ішемії та наступній реперфузії наростали у ранньому реперфузійному періоді та досягали найбільшого вираження через 1 добу реперфузії, а у пізньому реперфрузійному періоді відбувався зворотний їх розвиток. За умови корекції порушень карбацетамом відбувається зменшення ступеня ураження та пришвидшення відновлення структури скелетних м'язів кінцівки.

Ключові слова: гостра ішемія; реперфузія; скелетні м'язи; гістологічні зміни; артеріальний турнікет; карбацетам.

\section{ВСТУП}

Кровоспинні артеріальні турнікети широко застосовуються як у військовій медицині при пораненнях кінцівки, так і при хірургічних втручаннях на кінцівках (зокрема при ангіо- та артропластиках) $[1,2]$. Після зняття турнікета і відновлення кровопостачання кінцівки виникає багатофракторне ішемічно-реперфузійне ураження як первинно ішемізованих, так і віддалених від місця ішемії тканин [3, 4].

Вивченню структурних змін гемомікроциркуляторного русла та м'яких тканин кінцівок при розвитку даного синдрому присвячено низку досліджень [5-7], проте ефективність застосування ноотропних препаратів для корекції морорологічних порушень при ішемії-реперфузії потребує всебічного вивчення. Зважаючи на позитивний досвід застосування карбацетаму при ураженнях центральної нервової системи, а також ушкодженні внутрішніх органів при політравмі в експериментальних тварин, у даному дослідженні здійснено спробу визначити ефективність його застосування при ішемічно-реперфузійному ушкодженні скелетних м'язів щурів $[8,9]$.

Метою дослідження було провести порівняльний аналіз структурних змін у скелетних м'язах задніх кінцівок щурів при гострій ішемії-репердузії, спричиненій накладанням артеріального джгута, при здійсненні корекції порушень карбацетамом. perimysium, disorders in the hemomicrocirculatory bed in the form of stasis, hyperemia and microthrombosis, diapedetic hemorrhages, significant leukocyte infiltration, deformation of muscle fibers and the disappearance of their striation, damage to the sarcolemma with the release of nuclei in endomysium, defibering of myofibrils, ruptures and fragmentation of fibers, violation of the linear arrangement of nuclei in them, the appearance of areas of myocytolysis. Subject to the correction of reperfusion disorders by cabacetam, there is a decrease in the degree of damage and more quick restoration of structure of the skeletal muscles, which is the most pronounced in groups of animals with reperfusion terms after 1 and 7 days. Complex of features indicates, that at the tissue level the administration of carbacetam not only reduces the ischemicreperfusion lesion of the myosymplast, but also accelerates the mechanisms of reparative rhabdomyohistogenesis.

Conclusions. Structural changes in the skeletal muscles of the limb after two-hour ischemia and subsequent reperfusion increased in the early reperfusion period and reached its peak after 1 day of reperfusion, and in the late period of reperfusion their reverse development took place. With the correction of disorders by carbacetam, the degree of damage is reduced and the recovery of the skeletal muscle structure of the limb is accelerated.

Key words: acute ischemia; reperfusion; skeletal muscles; histological changes; arterial tourniquet; carbacetam.

\section{МАТЕРІАЛИ I МЕТОДИ}

Проведено гістологічне дослідження скелетних м'язів задніх кінцівок 60 щурів за умов експериментальної гострої ішемії-реперфузії. У контрольній групі було 8 інтактних тварин.

Експеримент проводили в спеціально відведеному приміщенні Центральної науково-дослідної лабораторії Тернопільського національного медичного університету імені І. Я. Горбачевського МОЗ України і полягав у моделюванні ішемії шляхом накладання гумового джгута SWAT на задню праву кінцівку тварини на рівні пахвинної складки під тіопентал-натрієвим знеболюванням (40 мг х кгํㅡㄹ маси тіла). Ширина перетискання тканин становила 5-6 мм. Реперфузію моделювали шляхом відновлення кровообігу в раніше ішемізованій кінцівці унаслідок зняття кровоспинного турнікета через 2 год після його накладання.

Евтаназію тварин здійснювали шляхом декапітації під тіопентал-натрієвим знеболюванням (500 мг х кг ${ }^{1}$ маси тіла внутрішньочеревно), після чого проводили забір біологічного матеріалу. Дослідження проведені з дотриманням основних положень Закону України № 3447 - IV від 21.02.06 р. «Про захист тварин від жорстокого поводження» (2006), Правил проведення робіт з використанням експериментальних тварин, затверджених наказом МОЗ України № 755 від 12.08.1997 р., Європейської конвенції про захист хребетних тварин, що використовуються для дослідних та інших наукових цілей (Страсбург, 1986), Директиви Ради Європи 2010/63 EU щодо експериментів на тваринах. 
Під час експерименту дослідних тварин поділили на три групи:

- перша дослідна група - тварини із моделюванням ішемічно-реперсузійного ушкодження шляхом накладання турнікета на задню кінцівку на 2 год (30 щурів);

- друга дослідна група - тварини із моделюванням ішемічно-реперфузійного ушкодження шляхом накладання турнікета на задню кінцівку на 2 год, котрим у реперфузійному періоді з метою корекції внутрішньочеревно вводили 1-оксо-3,3,6-триметил1,2,3,4-тетрагідроіндоло[2,3-с]хінолін (карбацетам) в дозі 5 мг на кілограм маси тіла один раз на добу протягом усього репердузійного періоду (30 щурів);

- контрольна група - інтактні тварини (8 щурів).

Тварин першої та другої експериментальних груп поділили на 5 підгруп дослідження по 6 тварин у кожній. Модель раннього постішемічного періоду в обох групах була представлена трьома підгрупами тварин із реперфузійними змінами через 1 і 2 год та 1 добу, а модель пізнього реперфузійного періоду - двома підгрупами тварин через 7 та 14 діб після зняття турнікета.

Гістологічне дослідження проводили на кафедрі патологічної анатомії з секційним курсом та судової медицини Тернопільського національного медичного університету імені І. Я. Горбачевського МО3 України. Досліджували зрізи скелетних м'язів нижче ділянки накладання джгута. 3 парафінових блоків готували серії зрізів товщиною 4-5 мкм, виготовлені на мікротомі МС-2. Тканини фріксували в $10 \%$ розчині нейтрального формаліну, зневоднювали у спиртах наростаючої концентрації та просочували парафріном за загальноприйнятими методиками [10]. Гістологічні зрізи забарвлювали гематоксиліном і еозином, за ван Гізон та азаном за методом Гейденгайна.

Гістологічні препарати вивчали за допомогою лабораторного мікроскопа MICROmedSEO SCAN та фротографрували за допомогою фротоустановки Digital Camera for Microscope Science Lab DCM 820.

\section{РЕЗУЛЬТАТИ Й ОБГОВОРЕННЯ}

За допомогою гістологічного дослідження виявлено структурні зміни у скелетних м'язах задніх кінцівок щурів у стегновій та гомілковій ділянках нижче місця накладання артеріального турнікета як у групі тварин без медикаментозної корекції, так і в тварин 3 корекцією порушень карбацетамом, проте вираження цих змін було неоднаковим.

При аналізі гістологічних препаратів скелетних м'язів дослідних тварин контрольної групи виявлено, що м'язи на поздовжніх зрізах представлені волокнами, які незначно варіюють за товщиною. Саркоплазма гомогенна, світлого еозинофільного відтінку. Сублемально розміщені овальні ядра, які орієнтуються своєю довгою віссю паралельно волокнам і зрідка проникають у товщу сарколеми. Поперечну посмугованість на поздовжніх зрізах виявлено у вигляді прямих і рівномірно розміщених смужок (рис. 1).

На поперечних зрізах волокна округлі або округло-овальні, розділені пухкою тонковолокнистою сполучною тканиною - ендомізієм. Групи волокон об'єднані у пучки, які оточені перимізієм. В сполучній тканині у невеликій кількості розміщені срібробласти та гемокапіляри. Подекуди у перимізії виявлялися артеріальні та венозні судини малих і середніх розмірів.

При розвитку ішемічно-реперфузійного ушкодження тканин унаслідок двогодинного накладання артеріального турнікета виявлено виражені прогредієнтно наростаючі структурні зміни в скелетних м'язах ішемізованих кінцівок щурів, які виявлялися вже через 1 год реперфузії, і досягали найбільшого вираження у тварин раннього постішемічного періоду з терміном реперфузії через 1 добу.

Аналіз гістологічних препаратів через 1 год реперсрузії показав, що порівняно із контрольною групою, через 1 год після відновлення кровообігу в кінцівці наявна дезорганізація м'язових волокон. Міофібрили в товщі деяких волокон розволокнені, часто виявлялися ділянки без посмугованості. Нерідко мали місце розриви волокон та їх звивистість. Такі зміни поєднувалися із змінами саркоплазми, яка ставала гетерогенною, розпадалася на фррагменти. Ядра втрачали лінійне розташування. Часто виявляли осередки міоцитолізу. Перифокально наявні поліморфьноклітинні інорільтрати. Унаслідок гемомікроциркуляторних розладів виникав набряк перимізію та ендомізію.

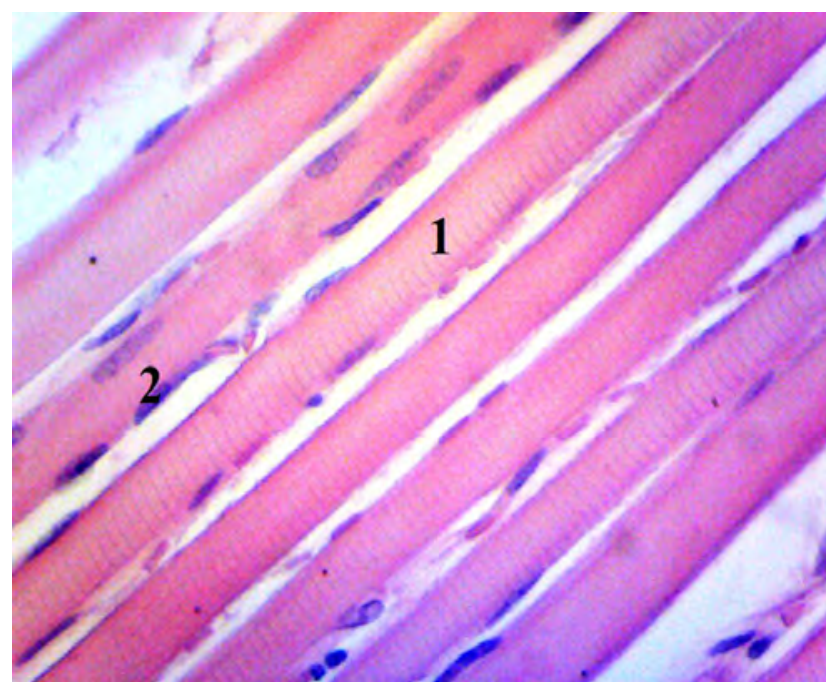

Рис. 1. Фрагмент поздовжнього зрізу скелетного м'яза стегна щура контрольної групи з добре візуалізованою поперечною посмугованістю. Ядра розміщені сублемально уздовж волокна. Забарвлення гематоксиліном і еозином. ×200.

Примітка. 1 - м'язове волокно; 2 - ядро міосимпласта. 
Через 2 год реперфузії дослідження патологічні зміни поглиблювалися. У скелетних м'язах у цей період виявлялися ті самі закономірності розвитку структурних змін, що і через 1 год реперсузії, проте вони ставали значно вираженіші, більш інтенсивні та дифрузі. Структурні зміни м'язових волокон прямопропорційно залежали від гемодинамічних розладів у гемомікроциркуляторному руслі. Світлооптично відмічалася гомогенізація м'язових волокон, їх звивистість, фррагментація, набухання та зникнення характерної посмугованості. В окремих випадках речовина саркоплазми була ущільнена i виражено оксиорільна. Волокна фррагментувалися в ряд послідовно розташованих глибок. Навколо таких ділянок та між фррагментами зруйнованих волокон виявлялися скупчення лімфоцитів, макрофрагів, гістіоцитів та поодиноких нейтроорілів (рис. 2).

При гістологічному дослідженні скелетних м'язів щурів через 1 добу реперфузії структурні зміни були найбільш вираженими і комплексними. Наростали прояви гемомікроциркуляторних розладів у вигляді стазу, гіперемії і мікротромбозів у мікросудинах. На поздовжніх зрізах м'язові волокна мали різну товщину, причому вона нерідко варіювала в межах одного волокна. Поперечна посмугованість простежувалася лише фррагментарно. Ядра втрачали своє лінійне розташування, частина з них виходила за межі волокон. Звичайними ставали ділянки деформації, оррагментації та розпаду волокон. Воскоподібна дегенерація змінювалася вакульною дистрофрією та лізисом. У всіх ділянках кінцівки характерною ознакою була наявність круглоклітинних запальних інфрільтратів та крововиливів навколо та в товщі ді-

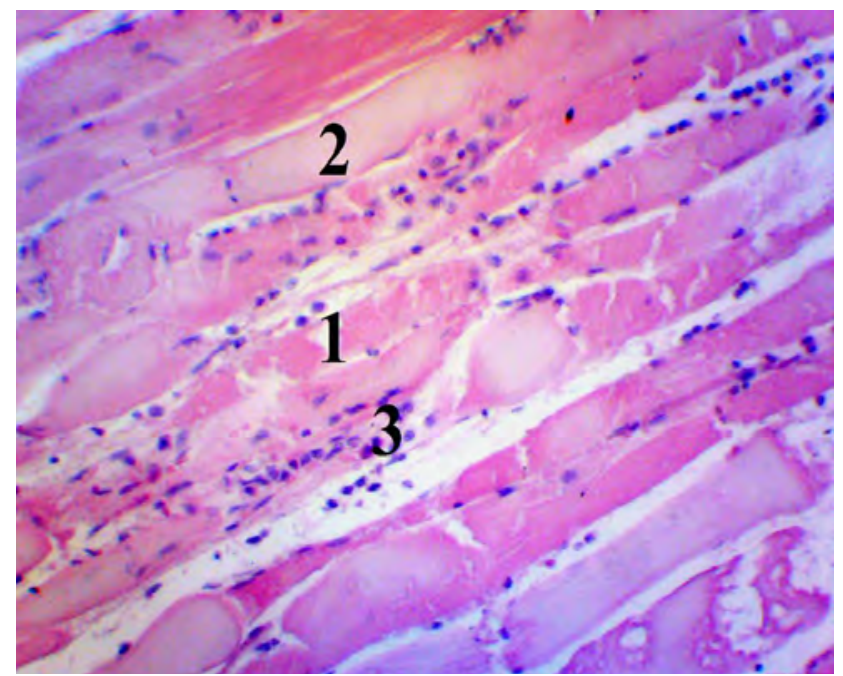

Рис. 2. Дегенеративно-деструктивні й некротичні зміни м'язових волокон із вираженою клітинною інфільтрацією. Фрагмент гомілкового м'яза щура через 2 год реперфузії. Забарвлення гематоксиліном і еозином. $\times 100$.

Примітка. 1 - фррагментація волокон; 2 - оксифрільна саркоплазма волокна та відсутність смугастості; 3 - клітинна інфільтрація. лянок міоцитолізису. На поперечних зрізах чітко виявлялися зони розмежування м'язових волокон набряклою сполучною тканиною та блідо-рожеві некротизовані елементи (рис. 3).

Через 7 діб реперфузії м'язові волокна світлооптично мали гетерогенний вигляд, змінювалися тинкторіальні властивості частини волокон. Поряд із незміненими виявляли волокна із нерівномірно забарвленою саркоплазмою. Збільшувалася частка атрофованих фрібрил. Окремі волокна, їхні групи або тільки частина волокна розпадалися на грудки різних розмірів. Поперечна посмугованість при цьому часто не виявлялася. Зрідка виявлялися осередки міоцитолізу із перифокальною круглоклітинною інфрільтрацією. Інтенсивні крововиливи не виникали. Лише місцями виявляли дифузне просякання гіпохромними еритроцитами.

Проте порівняно 3 попереднім терміном реперфузії (через 1 добу) ці зміни регресували. Разом з тим, виявлялися ознаки проліфрерації клітин фрібробластичного ряду та синтезу колагенових волокон. Скупчення м'язових волокон розмежовувалися полями рихлої сполучної тканини. В місцях крупноосередкових некрозів формувалася грануляційна тканина. Частка сполучнотканинного компонента зростала у стінках судин гемомікроциркуляторного русла та периваскулярно, що в результаті поглиблювало ішемічні впливи та сприяло подальшій фрібробластичній активності (рис. 4).

Мікроскопічне дослідження скелетних м'язів через 14 діб реперфузії показало найбільш повне відновленняїхньої структурипорівнянозусімапопереднімиперіодами. М'язовий масивбув компактний,

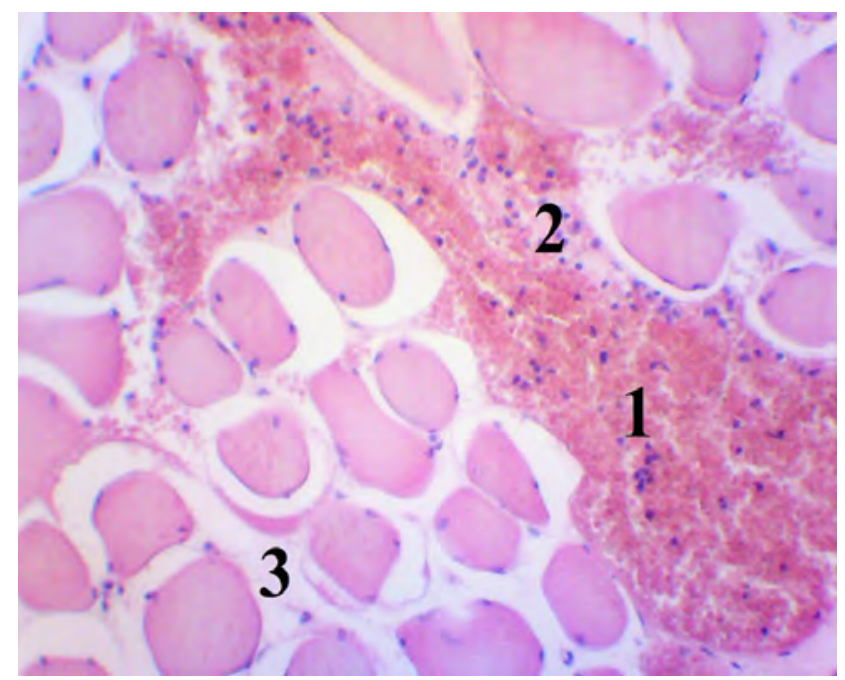

Рис. 3. Набряк, крововиливи у поєднанні 3 круглоклітинною інфрільтрацією. Фрагмент гомілкового м'яза щура через 1 добу реперфузії. Забарвлення гематоксиліном і еозином. ×100.

Примітка. 1 - крововилив; 2 - круглоклітинна інсрільтрація; 3 - набряк сполучної тканини навколо м'язових волокон.
ISSN 2706-6282(print) ISSN 2706-6290(online)
Вісник медичних і біологічних досліджень Bulletin of Medical and Biological Research
3(5),2020 


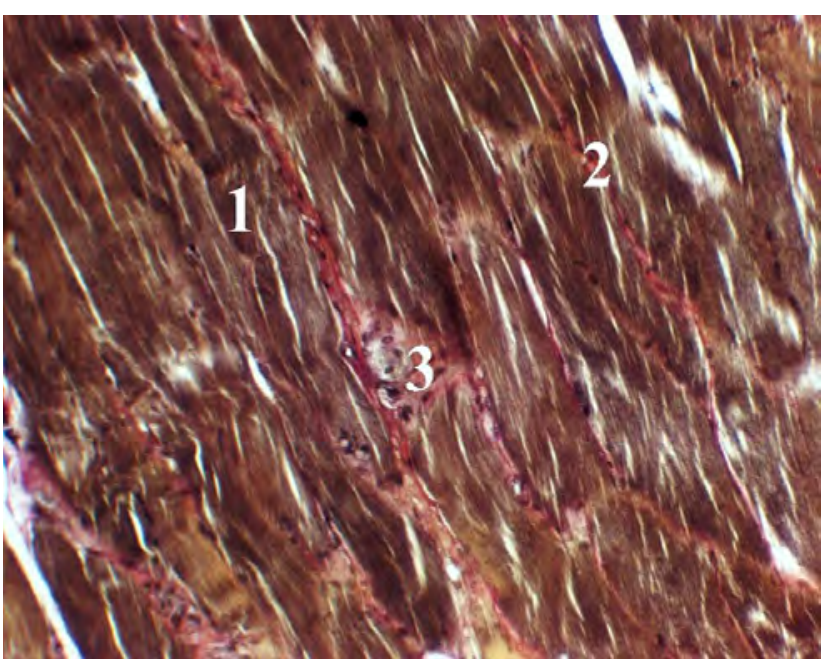

Рис. 4. Розростання сполучної тканини між м'язовими волокнами та в місцях їх ушкодження. Фрагмент стегнового м'яза щура через 7 діб реперфузії. Забарвлення азаном за Гейденгайном. ×40.

Примітка. 1 - м'язові волокна; 2 - розмежовування м'язових волокон сполучною тканиною; 3 - формування грануляційної тканини навколо осередків некрозів.

саркоплазма (за винятком) була однорідна, ядра - чітко контуровані й лінійно розташовані під сарколемою (рис. 5). Виняток складали ділянки, які підлягали деструкції. У цих місцях мала місце достатньо виражена проліферація волокнистої сполучної тканини та зберігалася клітинна інфрільтрація.

При дослідженні мікропрепаратів скелетних м'язів ішемізованих кінцівок щурів, яким вводили карбацетам, гістологічні зміни в ранньому репердузійному періоді виявлялися схожими як у тварин без корекції, проте вираження цих змін було меншим.

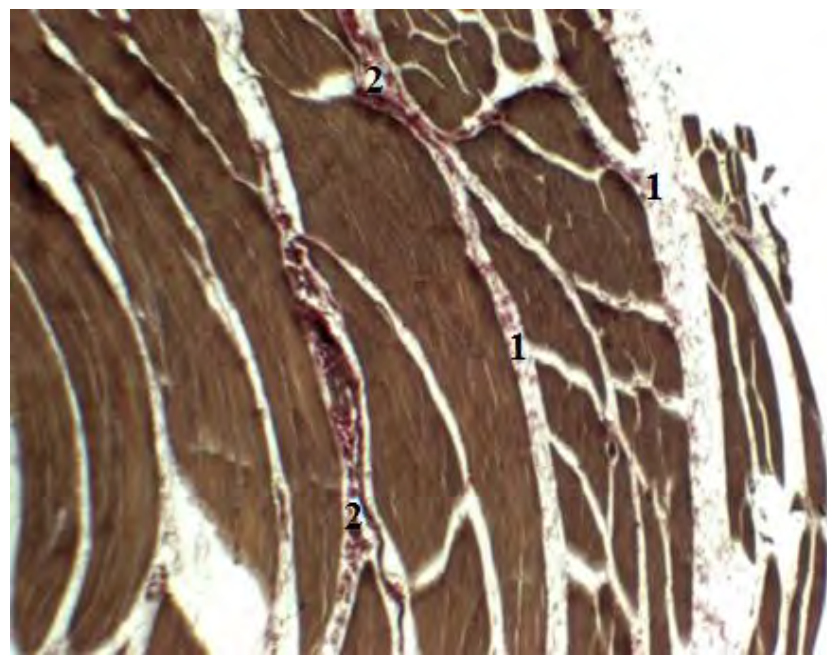

Рис. 5. Фрагмент структурно відновленого стегнового м'яза щура через 14 діб реперфузії. Забарвлення за ван Гізон. ×100.

Примітка. 1 - колагенові волокна в перимізію; 2 - накопичення колагенових волокон навколо судин гемомікроциркуляторного русла.
Через 1 год реперфузії відновлення кровотоку в кінцівці за умови корекції порушень карбацетамом виникали структурні порушення, подібні аналогічному терміну ішемії-реперфузії у тварин без корекції, і відмінності у вираженні цих змін в обох групах не були значними.

М'язові волокна світлооптично були гетерогенними. Поряд із незміненими виявляли волокна із нерівномірно забарвленою саркоплазмою. Нерідко виникали ділянки дезінтеграції м'язових волокон розрихленим ендо- та перимізієм. Міофібрили в товщі деяких волокон розволокнені. Визначали також ділянки без посмугованості. Нерідко виявлялися розриви волокон, їх звивистість. Такі зміни поєднувалися із змінами саркоплазми, яка була гетерогенною, розпадалася на фррагменти. Ядра втрачали лінійне розташування. Наявні осередки міолізу. У відповідь на такі зміни виявляли поліморфноклітинні інфрільтрати. Наростали прояви гемомікроциркуляторних розладів і пов'язаного 3 ними набряку перимізію та ендомізію (рис. 6).

При однотипності патологічних порушень в обох експериментальних групах у цей період, при порівнянні змін у тканинах 3 аналогічним періодом реперорузії у тварин без корекції, розміри осередків ушкодження та інтенсивність інфрільтратів були дещо меншими.

Дослідження через 2 год виявило прогресування структурних змін у м'язовій тканині, порівняно із попереднім періодом, і відповідало основним проявам у групі тварин без корекції, проте вираження їх було меншим порівняно 3 аналогічною групою тварин без введення карбацетаму.

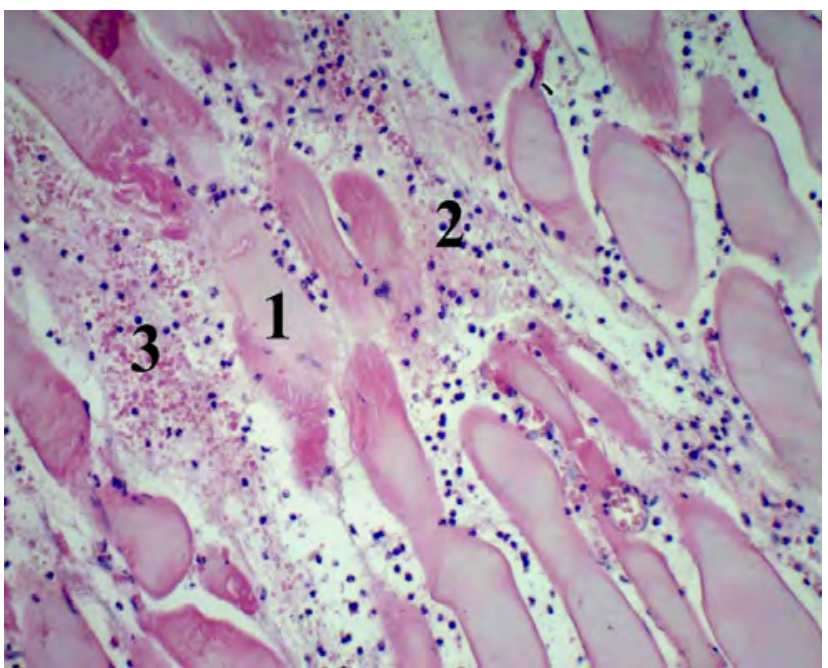

Рис. 6. Некроз і розпад поперечно-посмугованих волокон. Набряк сполучної тканини, крововиливи, дифузна клітинна інфільтрація. Фрагмент скелетного м'яза стегна щура через 1 год реперсузії із корекцією. Забарвлення гематоксиліном і еозином. ×100.

Примітка. 1 - міоцитоліз; 2 - дифууна клітинна інфрільтрація; 3 крововилив 
Порівняльна мікроскопія м'язової тканини у тварин із реперфузією через 1 добу показала, що за умови корекції карбацетамом при даному терміні реперсрузії були також наявні ділянки десрормації, фррагментації та розпаду волокон. Однак частота, з якою вони виявлялися, та розміри ділянок ураження були суттєво меншими порівняно з групою тварин без корекції. У тканині скелетних м'язів даної групи реактивна запальна реакція послаблювалася разом із скороченням іiі ареалу. В клітинних інфрільтратах збільшувалася частка макрофрагів та сполучнотканинних клітин - фрібробластів. Крововиливи відмічали зрідка і вони мали вигляд розсіяних інфрільтратів між фррагментами волокон і міоцитолізу. Набряк зберігався, хоча інтенсивність його була меншою, ніж у тварин без медикаментозної корекції. Виявляли ділянки компактного розташування м'язових волокон із поперечною посмугованістю. Незмінені ядра у таких ділянках мали лінійне сублемальне розташування (рис. 7). Серед описаних видозмінених поперечно-посмугованих м'язових волокон та збережених пластів виявляли й окремі атрофовані волокна.

Через 7 діб картина мікроскопічних проявів структурних змін м'язів суттєво змінювалася. Хоча кровонаповнення в системі гемомікроциркуляції залишалося нерівномірним, ознаки стазу виявляли лише спорадично, а тромбоз судин гемомікроциркуляторного русла не виявлявся взагалі, що свідчить про відновлення адекватного кровотоку в скелетних м'язах. Серед масиву поперечнопосмугованих м'язових волокон у цьому терміні некротичні та деструктивні зміни вже не спо-

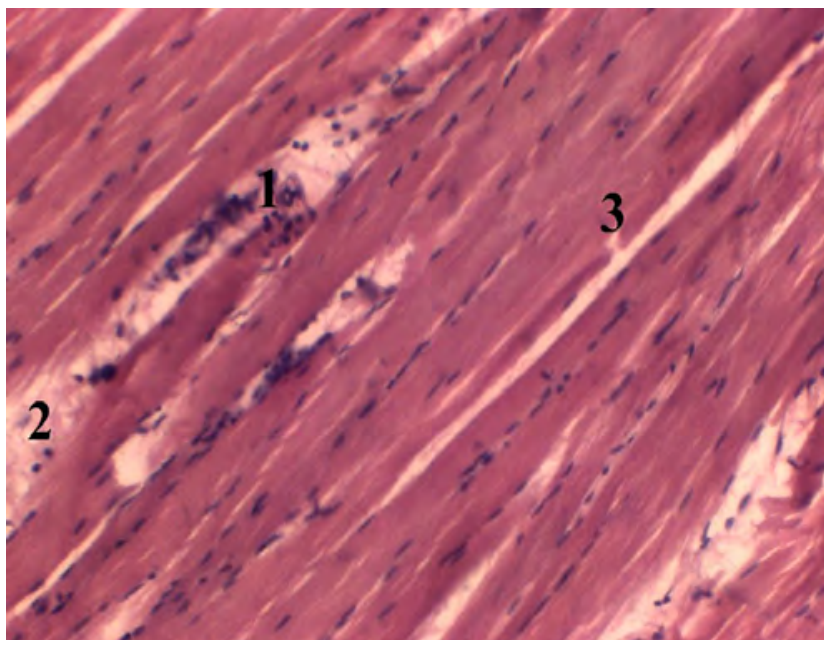

Рис. 7. Компактне розташування м'язових волокон з осередками ушкодження. Клітинна інфільтрація та набряк спорадичні й помірно виражені. Фрагмент скелетного м'яза стегна щура через 1 добу реперфузії із корекцією. Забарвлення гематоксиліном і еозином. $\times 100$.

Примітка. 1 - клітинна інфрільтрація; 2 - набряк між м'язовими волокнами; 3 - осередки ушкодження м'язових волокон. стерігалися, хоча все ще подекуди виявляли ділянки розволокнення міофібрил, девізуалізації поперечної посмугованості, набряк цитоплазми. Подекуди ідентифрікували м'язові трубочки структури з центрально розташованими ядрами, які свідчать про реактивну регенерацію скелетної м'язової тканини в цей період. Зменшення набряку сприяло відновленню компактного розташування м'язового синцитію, який візуально наближався до контрольної групи (рис. 8).

Через 14 діб дослідження структура скелетних м'язів практично повністю відновлювалася, лише виявляли незначні залишкові зміни, а також в ендо- і перимізію спостерігали помірне накопичення колагенових волокон (рис. 9).

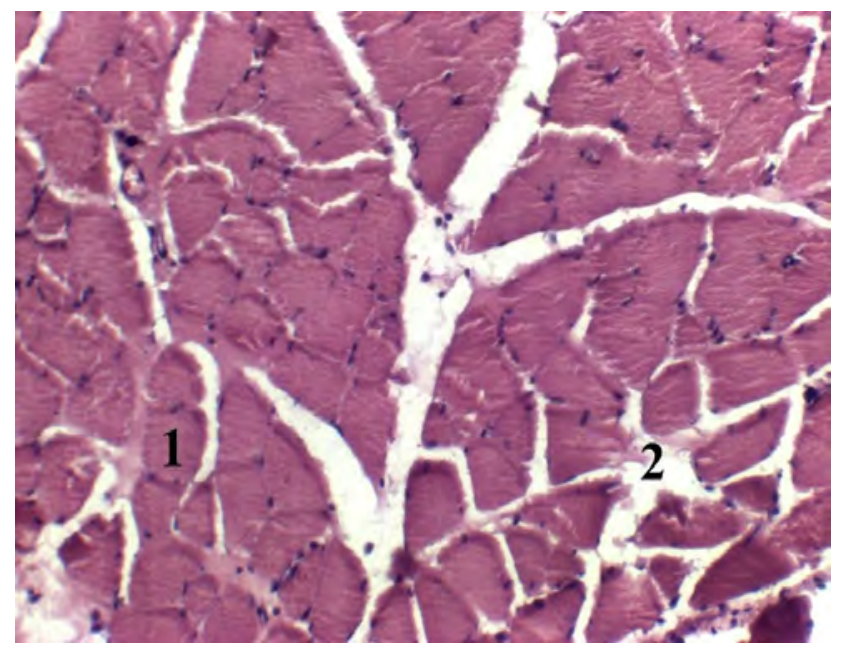

Рис. 8. Структурне відновлення м'язового синцитію - більшість волокон компактно розташована, ядра чітко контуруються під сарколемою. Поперечний зріз скелетного м'яза стегна через 7 діб реперфузії із корекцією. Забарвлення гематоксиліном і еозином. ×100.

Примітка. 1 - м'язове волокно з чітким розташуванням ядра під сарколемою; 2 - помірний набряк між м'язовими волокнами.

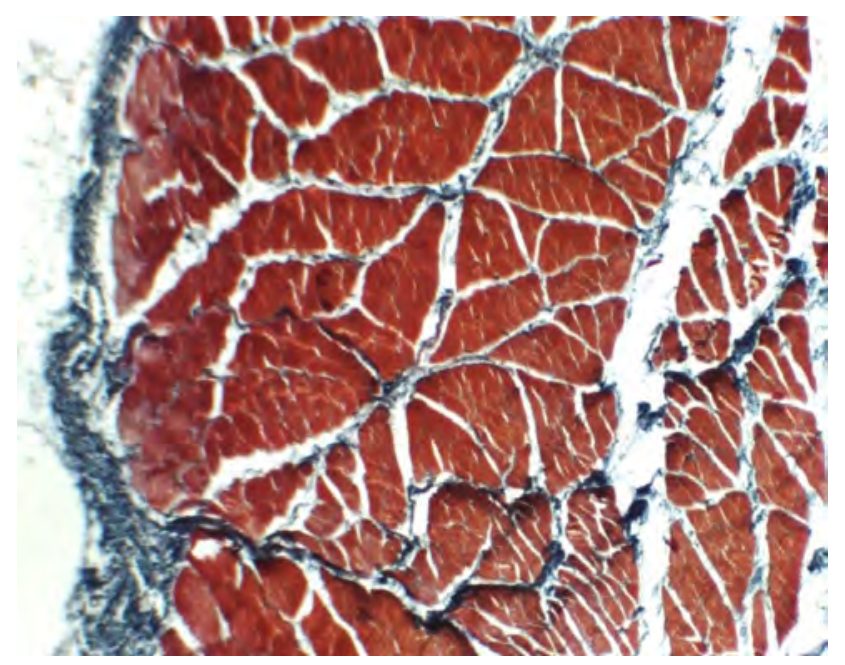

Рис. 9. Посилена колагенізація ендо- та перимізію м'яза гомілки щура через 14 діб реперфузії із корекцією. Забарвлення азаном за Гейденгайном. ×40.
Вісник медичних і біологічних досліджень Bulletin of Medical and Biological Research

\section{$3(5), 2020$}




\section{ВИСНОВКИ}

1. При двогодинному накладанні артеріального турнікета на задню кінцівку в щурів раннього постішемічного періоду розвивається ішемічнореперфузійне ремоделювання скелетних м'язів нижче місця накладання джгута, яке проявлялося комплексом структурних змін м'язової тканини вже через 1 год реперфузії, наростало через 2 год, і досягало максимального вираження у тварин із реперфузією через 1 добу.

2. Основними гістологічними ознаками ішемічно-реперфузійного ураження скелетних м'язів кінцівки були: виражений набряк м'язових волокон та ендо- і перимізію, порушення гемомікроциркуляторного русла у вигляді стазу, гіперемії та мікротромбозу, діапедезні крововиливи, виражена лейкоцитарна інорільтрація, десрормація м'язових волокон, втрата їх посмугованості, ушкодження сарколеми з виходом ядер у ендомізій, розволокнення міофібрил, розриви та фррагментація волокон, порушення лінійного розміщення ядер у них, поява ділянок міоцитолізу, виражені зміни тинкторіальних властивостей м'язової тканини.

3. На етапах постішемічної реперфузії за умови корекції карбацетамом відбувається поступове зменшення ступеня ураження та пришвидшення відновлення структури скелетних м'язів кінців-

\section{СПИСОК ЛІТЕРАТУРИ}

1. New tourniquet device concepts for battlefield hemorrhage control / J. F. Kragh, C. Murphy, M. A. Dubicket [et al.] // Army Med. Dept. J. - 2011. - P. 38-48.

2. Tourniquet-induced ischaemia during total knee arthroplasty results in higher proteolytic activities within vastus medialis cells: a randomized clinical trial. / A. Jawhar, S. Hermanns, N. Ponelies [et al.]. - 2016. - Vol. 24 (10). P. 3313-3321. Epub 2015 Nov 14.

3. Use of a tourniquet in total knee arthroplasty: a systematic review and meta-analysis of randomized controlled trials / F. Jiang, H. Zhong, Y. Hong, G. Zhao. J. Orthop. Scien. // Knee Surg. Sports Traumatol Arthrosc. - 2015. Vol. 20, No. 1. - P. 110-123.

4. Protective effects of modeled superoxide dismutase coordination compound (MSODa) against ischemia/ reperfusion injury in rat skeletal muscle / X. T. Wang, Y. Tian, W. X. Xu [et al.] // Cell Physiol. Biochem. - 2015. Vol. 37 (2). - P. 465-476. Epub 2015 Aug 28.

5. Кутепов Д. Е. Патогенез синдрома ишемии-реперфузии / Д. Е. Кутепов, М. С. Жигалова, И. Н. Пасечник //

\section{REFERENCES}

1. Kragh JF, Murphy C, Dubick MA, Baer DG, Johnson J, Blackbourne LH. New tourniquet device concepts for battlefield hemorrhage control. US Army Med Dept J. 2011;38-48. ки. Якщо через 1 год реперфузії у тварин як без корекції, так і за умови корекції структурні зміни скелетних м'язів були подібними і не виявлялося значних відмінностей, то на подальших етапах у групі щурів, яким проводили медикаментозну корекцію карбацетамом, порівняно 3 групою тварин без корекції, виявлялася позитивна наростаюча динаміка зі стабілізацією патологічного процесу та максимально можливим структурним відновленням вже через 7 діб після відновлення кровообігу в кінцівці.

4. Відмінність між групами тварин із корекцією карбацетамом та без неї найбільш виразно виявлялася у групах щурів із реперфузійними термінами через 1 добу та 7 діб. У тварин з корекцією через 1 добу реперорузї вираження гістологічних змін було суттєво меншим, ніж у тварин без корекції. При застосуванні карбацетаму істотне зменшення ознак ремоделювання скелетних м'язів і відновлення їх структури відбувалося вже через 7 діб реперфузії - тоді як у тварин без корекції нормалізація порушень та повернення їх до рівня інтактної групи тривала до кінця 14 доби реперфузії.

5. Сукупність гістологічних ознак свідчить про те, що на тканинному рівні при введенні карбацетаму зменшується ішемічно-реперфузійне ураження міосимпласта та пришвидшуються механізми репаративного рабдоміогістогенезу.

Казанский медицинский журнал. - 2018. - № 99 (4). C. $640-644$.

6. Tennant D. The role of HIFs in ischemia-reperfusion injury / D. Tennant, N. J. Howell // Hypoxia. - 2014. Vol. 2. - P. 107-111.

7. Walters T. J. Activity attenuates skeletal muscle fiber damage after ischemia and reperfusion / T. J. Walters, K. Garg, B. T. Corona // Muscle Nerve. - 2015. - Vol. 52 (4). - P. 640-648. Epub 2015 Aug 14.

8. Козак Д. В. Вплив карбацетаму на антиоксидантно-прооксидантний баланс тканини серця, легень і печінки в динаміці політравми / Д. В. Козак // Шпитальна хірургія. - 2014. - № 1. - С. 40-42.

9. Експериментальне дослідження впливу карбацетаму на стан тканин гіпоталамусу при черепно-мозковій травмі / С. В. Зябліцев, Т. І. Панова, О. О. Стародубська, О. О. Дядик // Медична наука України. - 2018. - Т. 14, № 1-2. - С. 11-17.

10. Саркисов Д. С. Общая патология человека / Д. С. Саркисов М. А. Пальцев, Н. К. Хитров. - М. : Медицина, 1997. - 608 с.

2. Jawhar A, Hermanns S, Ponelies N, Obertacke U, Roehl $\mathrm{H}$. Tourniquet-induced ischaemia during total knee arthroplasty results in higher proteolytic activities within vastus medialis cells: a randomized clinical trial. Knee 
Surg Sports Traumatol Arthrosc. 2016;10(4): 3313-21. DOI: 10.1007/s00167-015-3859-2. Epub 2015 Nov 14.

3. Jiang FZ, Zhong HM, Hong YC, Zhao GF. Use of a tourniquet in total knee arthroplasty: a systematic review and meta-analysis of randomized controlled trials. J Orthop Sci. 2015;20(1): 110-23. DOI: 10.1007/s00776-014-0664-6.

4. Wang XT, Tian Y, Xu WX, Cui LH, Xiang SY, Lu SC. Protective effects of modeled superoxide dismutase coordination compound (MSODa) against ischemia/ reperfusion injury in rat skeletal muscle. Cell Physiol Biochem. 2015;37(2): 465-76. DOI: 10.1159/000430369. Epub 2015 Aug 28

5. Kutepov DE, Zhigalova MS, Pasechnik IN. [Pathogenesis of ischemia-reperfusion syndrome]. Kazanskiy med zhurn. 2018;99(4): 640-4. DOI: 10.17816/ KMJ2018-640. Russian.
6. Tennant D, Howell NJ. The role of HIFs in ischemiareperfusion injury. Hypoxia. 2014;2: 107-11. DOI: $10.2147 /$ HP.S49720.

7. Walters TJ., Garg K, Corona BT. Activity attenuates skeletal muscle fiber damage after ischemia and reperfusion. Muscle Nerve. 2015;52(4): 640-48. DOI: 10.1002/mus.24581. Epub 2015 Aug 14.

8. Kozak DV. [Effect of carbacetam on antioxidant and prooxidant balance of heart, lungs and liver tissues in polytrauma dynamics]. Shpyt khirur. 2014;1: 40-2. Ukainian.

9.ZiablytsevSV,PanovaTI, StarodubskaOO, DyadikOO. [Experimental investigation of carbacetam influence on hypothalamus tissue in brain injury]. Med nauka Ukr. 2018;14(1-2): 11-7. DOI: 10.32345/1998-3719.1-2.2018.02. Ukrainian.

10. Sarkisov DS, Palcev MA, Khitrov NK. General human pathology [Общая патология человека]. Moscow: Meditsina; 1997. Russian. 